\title{
Platón: la experiencia de la verdad ${ }^{1}$ Plato: The Experience of Truth
}

JOSU LANDA

Facultad de Filosofía y Letras

UNIVERSIDAD NACIONAL AUTÓNOMA DE MÉXico | México

Contacto: josulanda@filos.unam.mx

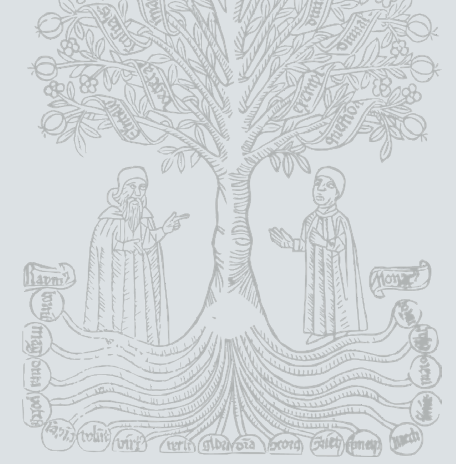

\section{Resumen:}

En varios diálogos de Platón se da cuenta del acontecer de una visión de cierto modo de la realidad en sí, como una experiencia resultante de un proceso intencional de generación de representaciones noéticas. En general, el método dialéctico hace posible que el "noús" ("inteligencia" o "entendimiento", algo como la "facultad" de aprehensión de las realidades inteligibles) efectúe lo que bien podría designarse con el término "experiencia de la verdad", es decir, la contemplación del "espectáculo de la verdad" o el acceso del alma de quien conoce a la representación nítida de lo que se le ofrece como ser en sí. En las líneas subsiguientes, se pretende mostrar que en el pensamiento platónico la meta teórica por la que se mueve el auténtico filósofo es la episteme noética; que ese modo de la verdad es un acontecimiento repentino, surgido a la vera de disposiciones, prácticas y procedimientos que acondicionan el alma para ese fin; que tal evento se da a manera de experiencia que deja secuelas profundas en el alma, con las que se enriquece y revitaliza, y que el alma así afectada conjuga capacidades para acceder siempre al saber más elevado, practicar las más altas virtudes y ejercer la política justa.

Palabras clave: episteme noética, acontecimiento, subitaneidad (exaíphnes), nóema, experiencia, purificación del alma

\begin{abstract}
:
Several Platonic dialogues provide an account of the event that comes with a particular regard of reality in itself, as an experience resulting from an intentional process of noetic representations. In general, the dialectic method enables "noús" (an intelligence or understanding, a faculty to apprehend intelligible realities) to realize what could be termed "experience of truth"-in other words, the contemplation of the "performance of truth" or how the soul of the knower accesses a clear representation of what appears as being in itself. This article intends to show that in Platonic thought, the theoretical objective by which the authentic philosopher moves is the noetic episteme; that this truth's mode is a sudden event arising from the dispositions, practices, and procedures that condition the soul for that purpose; that such an event takes place as an experience that leaves profound consequences in the soul, such as enriching and revitalizing it, and that the affected soul combines capabilities to always access the higher knowledge, practice the highest virtues, and choose fair politics.
\end{abstract}

Keywords: noetic episteme, event, subitaneity (exaíphnes), nóema, experience, purification of the soul

1 Artículo invitado. 


\section{El acontecer de la verdad en sí}

En varios diálogos de Platón se da cuenta del acontecer de una visión de cierto modo de la realidad en sí, como una experiencia resultante de un proceso intencional de generación de representaciones noéticas. ${ }^{2}$ En general, el método dialéctico hace posible que el "noús" ("inteligencia" o "entendimiento", algo como la "facultad" de aprehensión de las realidades inteligibles) efectúe lo que bien podría designarse con el término "experiencia de la verdad", es decir, la contemplación del "espectáculo de la verdad" ${ }^{3}$ o el acceso del alma de quien conoce a la representación nítida de lo que se le ofrece como ser en sí. Puede referirse, como un ejemplo ilustrativo de lo dicho, la parte final del discurso de Diotima de Mantinea en Banquete. La sabia extranjera le advierte a Sócrates que el resultado del proceso dialéctico -el nóema de lo bello absoluto- no será ningún objeto hermoso sujeto a las determinaciones del devenir, sino "la belleza en sí", aquella "que es siempre consigo misma específicamente única".

Lo que en un primer momento cabe destacar en la densa relación platónica de la tesis de Diotima es el hecho de que la verdad no es el simple registro discursivo de un correcto ajuste de la mente a la cosa -adaequatio intellectus ad rem-, sino el acontecimiento de una experiencia, una afección precisa en la subjetividad de quien procura conocer una realidad concreta - lo bello- y al fin la conoce o representa. El suceso puntualmente referido es el de la contemplación inmediata de la belleza absoluta. Esa visión extraordinaria -en tanto que más amplia, intensa, vivaz, compleja y profunda que las percepciones visuales ordinarias - resulta de un esfuerzo que, según recomendación de la sapientísima erotóloga, conviene emprender desde la juventud y debe durar lo suficiente para ascender por una serie de "escalones", hasta llegar al "mar de lo bello". Se trata, pues, del desenlace de un proceso: una serie de avances

\footnotetext{
2 Se entiende aquí por "nóesis" el acontecimiento de la adecuación plena del alma representadora con la entidad objetiva representada. Se trata de la máxima expresión de la epistéme, por encima de la diánoia ("pensamiento discursivo"), de acuerdo con los niveles de acceso a lo real propuestos por Platón en su Alegoría de la Línea (Platón, República, 509e-511e).

3 Platón, República: 475e

4 Platón, Banquete: 211 b
} 
que, en su apropiada articulación, hace posible un resultado, en este caso, de carácter rigurosamente epistémico.

Esa condición estrictamente eventual y procesual - dialéctica- de la producción de verdad, apreciable en las palabras de Diotima, trae aparejado otro aspecto digno de la mayor atención: la experiencia de la verdad acontece súbitamente (exaiphnes), sin que sea evidente ni se pueda explicitar con precisión la manera en que la vinculación efectiva de los elementos que intervienen en el proceso dialéctico posibilita el evento en referencia. Según el texto platónico, sucede que "quien hasta aquí [es decir, hasta el último de los 'peldaños' detallados por Diotima] haya sido instruido en las cosas del amor, tras haber contemplado las cosas bellas en ordenada y correcta sucesión, descubrirá de repente (exaiphnes)", la referida belleza en sí. ${ }^{5}$

En la última sección de su fino estudio titulado "¿Propone el Banquete una ciencia del amor?", Francisco Bravo (2013) detalla los términos de la "síntesis en obra" que observa en el discurso de Diotima. La expresión luce afortunada en la medida en que evidencia un proceso general de síntesis - un movimiento dialéctico - que, a fin de cuentas, engloba varios momentos de reducción sintética: cuando menos, el que absorbe y redimensiona las diversas tesis de los interlocutores de Sócrates en el simposio, el que coloca implícitamente la materia investigada en el plano de la teoría de las Ideas, el que permite establecer un objeto preciso del amor, el que asienta los límites del viejo Eros de la mitología, figurado ahora como semidivinidad a la vez carente y dotada de poderes efectivos, el que deriva en la determinación de la naturaleza del amor socrático-platónico, el que sitúa el sentido de las virtualidades eróticas en el ámbito de la felicidad... (Bravo, 2013: 132-134). Sin menoscabo de la pertinencia, la fecundidad exegética y la claridad de esa meticulosa lectura de Bravo, se echa en falta en ella un examen de dos aspectos interconectados: el de la visión repentina de la realidad, a la que se ha dirigido el esfuerzo del amante-filósofo, y la condición absoluta de ese ser intuido de esa manera. Es del todo evidente que las palabras de la extranjera de Mantinea van más allá del registro discursivo de un proceso de producción teórica sustentado en la crítica y superación de las tesis sobre el eros expuestas por quienes participan en el diálogo simposíaco compuesto por Platón. Salta a la vista que el filósofo se esmera en remarcar un acontecimiento extradiscursivo y fuertemente

\footnotetext{
5 Platón, Banquete: 209e-210e
} 
experiencial, al término de la senda que Diotima traza para los fervorosos entusiastas de Eros.

Por su parte, Francesco Fronterotta (2013) se limita a establecer rigurosamente lo que él llama "tres niveles epistémicos" (tre liveli epistemici) en el discurso de Diotima: el que corresponde a una "visión o contacto" de índole perceptual de realidades sensibles, el que atañe a una "comprensión racional-discursiva" de la belleza universal captable en sus múltiples manifestaciones, tanto de carácter sensible como intelectual, y el que concierne a "una visión y un contacto" de cariz no sensible ni discursivo ni conceptual de lo bello en sí. Estamos ante una distinción jerárquica de grados, conforme con la cual el tercero es superior a los dos anteriores. En efecto, aun cuando siempre se trate de la misma belleza, el modo de su representación extrasensorial y extradiscursivo, "fusional" - aunque no ajeno a la razón ni a la ciencia-, propio del tercer nivel, comporta una conexión epistémicamente más honda, más plenamente real con aquella. De hecho, para Fronterotta, esa culminante contemplación inmediata de lo que Diotima ha definido como el objeto del amor viene a ser su más alta representación racional: "[il] più alto e conclusivo máthema del bello" [el más alto y conclusivo mathema de lo bello] (Fronterotta, 2013: 92).

Como puede observarse, el estudioso italiano repara bien en el rango de profundidad de cada nivel de experiencia en la relación de una subjetividad con la belleza, pero no se detiene a considerar el asunto del acontecer repentino con que se cumple el de alcance más elevado. Por ello, aun cuando en el escrito mencionado - como en otros - se aplica en caracterizar la clase de realidad que constituye la idea de lo bello y así marca la diferencia ontológico-epistémica de los referidos niveles de conocimiento, Fronterotta parece defender una continuidad de menor a mayor entre ellos. Es decir, no destaca en su lectura algo que el propio Platón resalta, esto es, una ruptura en el plano de los procesos de actividad representativa, entre el modo supremo de conocimiento de lo bello y los que le anteceden.

El hecho de que la verdad absoluta acontezca de súbito, de improviso, de manera que cabe imaginar irruptiva, una vez alcanzado el nivel más elevado de intelección de "bellos conocimientos", parece marcar una distinción de dos niveles y aun modos de saber: el que corresponde a los esfuerzos de cariz dialéctico -claramente controlados por la razón y progresivos-, y el que concierne a la contemplación inmediata y absoluta - es decir, "ab-suelta" de sus antecedentes de índole discursiva (dianoética) y empírica- que tiene como 
correlato una realidad igualmente absoluta. Es lo que podría inferirse de lo que la propia Diotima caracteriza como "la manera correcta de acercarse a las cosas del amor", consistente en empezar:

Por las cosas bellas de aquí y, sirviéndose de ellas como peldaños, ir ascendiendo continuamente, con base en aquella belleza, de uno solo a dos y de dos a todos los cuerpos bellos y de los cuerpos bellos a las bellas normas de conducta y de las normas de conducta a los bellos conocimientos y, partiendo de éstos, terminar en aquel conocimiento no de otra cosa sino de aquella belleza absoluta. ${ }^{6}$

El apego fiel al texto platónico no autoriza a inferir, de manera inobjetable, la existencia de un vínculo de necesidad entre los "peldaños" que 1levan a la representación verdadera de la belleza y la experiencia de la visión de la belleza absoluta, pero tampoco niega esa posibilidad. El hecho de que Diotima hable de un acontecimiento repentino, después de haberse esmerado en diferenciar los diversos pasos reductivos de la dialéctica erótica, comporta cuando menos una paradoja, a saber, dichos pasos previos operan como momentos discursivos, dianoéticos, que sin embargo derivan en un evento intuitivo, noético - "fusional", como le llama Fronterotta-. La contradicción estriba en que un proceso discursivo y gradual aparece en las palabras de la sabia extranjera como condición de un suceso irruptivo, como si lo noético no fuera posible sin unos avances dianoéticos previos. Pero, el mismo carácter eventual, subitáneo y, por ende, en algún grado sorprendente, de la contemplación de lo bello en sí podría implicar la posibilidad de prescindir de la esforzada labor de ascensión dialéctica en pos de su cumplimiento, pero es claro que Platón no reivindica explícitamente tal probable prescindencia.

Es difícil establecer con precisión la razón de esa paradoja. Acaso se deba a que, en el ámbito del socratismo platónico, se asume como algo "lógico" que la concreción rigurosa de la síntesis detallada por Bravo, así como la realización de los pasos "reductivos" que registra Diotima, operan como antecedente necesario de un fenómeno experiencial del que no se puede dar cuenta de modo discursivo-proposicional. Si este fuera el caso, sería lícito concluir que Platón se cerraría a la posibilidad de acceder a lo bello en sí por parte, por ejemplo, del poeta entusiasmado del que el propio filósofo habla en Ion y, verbigracia, tornaría inconcebibles figuras como el entusiasta renacentista,

\footnotetext{
${ }^{6}$ Platón, Banquete: 211b-c
} 
siempre hirviendo en furores eróticos, o el genio schopenhaueriano, capaz de desbordar las restrictivas lindes del principio de razón, para acceder sin mediaciones a los dominios de la Voluntad.

E1 proceso que permite concluir en la proposición "los equinos son vivíparos", por caso, evidencia el carácter discursivo propio de la lógica de clases, pero sería insólito que alguien que profesara la ciencia de la zoología se hallara, al formularla, a las puertas de la visión inmediata de algo como la vida en sí o la reproductividad animal en sí. Lo mismo cabría imaginar, tratándose de otras producciones adscritas al ámbito de lo dianoético-discursivo, como por ejemplo la ecuación algebraica $\mathrm{a}^{2}+\mathrm{b}^{2}=\mathrm{c}^{2} \mathrm{o}$ el enunciado "El capitalismo neoliberal ha incrementado la desigualdad social en nuestro tiempo". Se puede ampliar la lista de ejemplos hasta límites indefinibles por su extensión - tan sólo con pensar en la producción discursiva de las ciencias basta, para esperar cantidades inabarcables - sin que se piense en la certera probabilidad de que tan vasta copia de casos derive en una cascada de acontecimientos asimilable a la experiencia de lo real absoluto de la que da cuenta Diotima. Importa tener presentes los límites más que obvios del pensamiento discursivo, en la medida en que ello permite resaltar lo que está en juego en el súbito salto (exaíphnes) por el que se accede a la captación noética de la belleza absoluta, tras haber bregado con rigor y perseverancia en el uso dialéctico del lenguaje.

Y ¿qué es lo que está en juego en la advertencia diotímea de que, tras el proceso dianoético-dialéctico, acontece de repente (exaíphnes) la visión dialéctico-noética de la belleza absoluta? No parece posible alcanzar una conclusión apodíctica en el intento de responder esa pregunta, pero nada impide constatar, de entrada, que estamos ante el registro inevitablemente limitado e impreciso de algo como una superación indeterminable del devenir. Se diría que el recurso apropiado a la dialéctica posibilita el acceso a otro estado de lo real objetivo y de lo real anímico-subjetivo. Aunque el lenguaje ordinario y el de cariz técnico-filosófico son por completo deficientes para dar cuenta de esa singular situación, sí puede afirmarse que se experimenta como algo que ya no está sujeto al tiempo ni al espacio ni a la causalidad operantes en la realidad ordinaria de la que participa la dinámica dianoética-discursiva. De ahí la condición instantánea, "eterna" (atemporal), indeterminada, de la experiencia de vérselas con una realidad igualmente incondicionada, absoluta. En palabras de Bravo (2002), lo que resulta del proceso dialéctico descrito por Diotima, "el acto por el que el hombre alcanza 'la esencia de lo bello', es una visión súbita, un acto contemplativo cumplido por noûs" (278), y no por la actividad 
de ningún sentido ni por un raciocinio lógico. Así pues, el acontecimiento en referencia se da de improviso, porque es propiamente absoluto: ya no está sujeto al tiempo por las ligaduras de la representación perceptual y sensible ni por representaciones procedentes de un proceso inferencial, demostrativo.

Aparte de lo dicho, la referencia al acontecimiento súbito (exaíphnes) de la visión de lo absolutamente real marca la diferencia en sus relaciones con el tiempo, por parte del pensamiento dianoético-discursivo y el de índole dialéctica-noética, aunque el propio Platón no se detenga a explicitar tal distinción. Podría pensarse que el inexplicado y paradójico vínculo entre lo dianoético y lo noético evidencia una limitación del pensamiento platónico, algo de lo que Platón no pudo dar razones suficientes, de manera equiparable a las aporías que su propia teoría de las Ideas supone en la parte tocante a los nexos entre aquellas y los entes singulares presentes en el mundo de lo sensible, por ejemplo, en Parménides. Con todo, no parece tratarse de un simple defecto expositivo del discurso de Diotima o de la manera de registrarlo por parte de Platón. Si ese fuera el caso, sería muy extraño que el filósofo reincidiera en la misma supuesta "falla", pues la omisión que aquí se plantea vuelve a darse al final del libro vi de República, que es donde se expone la Alegoría de la Línea. Como es bien sabido, la parte de la línea correspondiente a la episteme, por contraste con la de la doxa, se divide en dos secciones: la que concierne al saber discursivo, en general, y la que atañe a los procederes dialécticos que derivan en una superación de toda determinación sensible y, así, al colocarse en exclusiva en el plano de las Ideas, deviene visión directa y aprehensión inmediata de Ideas. ${ }^{7}$

Según puede apreciarse aquí, la subitaneidad del acontecer de la experiencia consistente en la captación inmediata de lo real equivale a superación de

\footnotetext{
7 No estará de más aproximarse de nueva cuenta a lo que trata de asentar Sócrates, cuando en República (511a-e) recurre didácticamente a la Alegoría de la Línea. Allí se establece, a lo menos, lo siguiente: 1) En la sección concerniente al modo de conocimiento que opera de cara a las cosas sensibles, se refiere que "el alma se ve forzada a servirse de supuestos en su búsqueda, sin avanzar hacia un principio". 2) Por su parte, en el ámbito de lo inteligible, "la razón misma aprehende, por medio de la facultad dialéctica y hace de los supuestos, no principios, sino realmente supuestos, que son como peldaños y trampolines hasta el principio del todo, que es no supuesto y, tras aferrarse a él, ateniéndose a las cosas que de él dependen, desciende hasta una conclusión, sin servirse para nada de lo sensible, sino de las Ideas, a través de las Ideas y en dirección a Ideas, hasta concluir en Ideas". 3) En vista de lo anterior, el "pensamiento discursivo" se muestra como "algo intermedio entre la opinión y la inteligencia". 4) Además, las cuatro secciones de la línea remiten a otras tantas afecciones: "inteligencia, a la suprema; pensamiento discursivo, a la segunda; a la tercera asigna la creencia y la cuarta, a la conjetura". 5) Finalmente, "cuanto más participan de la verdad [dichas afecciones], tanto más participan de la claridad" (Platón, República: 511a-e).
} 
las determinaciones empíricas - espaciales, temporales y causales - del pensar discursivo proposicional, en cuanto manifestación de la dinámica del alma, al entrar en contacto con la realidad eidética. "Superar" puede connotar, aquí, actos como los de "remontar", "dejar atrás", "pasar a otro orden de realidad", "emanar una novedad", todos ellos relacionados con la actividad del alma, algo que el propio Platón procura describir, echando mano de la metafórica del fuego, en la séptima de sus cartas. En medio de vehementes afanes por denunciar ciertas prácticas de falsos filósofos, como la consistente en publicar textos "de filosofía", Platón deja sentado que los temas realmente filosóficos "no se pueden [...] precisar como se hace con otras ciencias, sino que después de una larga convivencia con el problema y después de haber intimado con él, de repente, como la luz que salta de la chispa, surge la verdad en el alma y crece ya espontáneamente". ${ }^{8}$

Esa manera de describir el acontecimiento de la verdad abre campo a diversos problemas. Acaso el más difícil de ellos sería el de dar razón clara y bien fundada del "salto" que lleva a la visión repentina del objeto en sí, tras toda la labor sistemática y prolongada que comporta el riguroso proceso dialéctico. No está del todo clara la relación entre un proceso inferencial como la dialéctica y la subitaneidad e inmediatez de la experiencia de inteligir lo real. Cabría preguntar, entonces, si este método filosófico por excelencia se limita a dar cumplimiento al propósito de preparar las condiciones de apertura anímica para el acontecer de la alétheia, la visión nítida de lo real absoluto. Si ese fuera el caso, ¿significaría que Platón también coloca, de manera implícita, a la dialéctica en los dominios del pensamiento discursivo, aunque hable de una "ciencia dialéctica" (dialégesthai epistémes)? ¿'Sería la dialéctica algo como una "ciencia auxiliar" de la alétheia como tal? ¿Significaría, asimismo, que el filósofo distingue por completo, de manera excluyente, el meticuloso esfuerzo heurístico que implica la dialéctica con respecto al fruto que prodiga -la contemplación de la verdad última, raigalmente apodíctica, del objeto de investigación? ¿O simplemente se trata de un falso problema fácil de despachar, con un decidido recurso a la navaja de Occam? He aquí un tema de investigación para otra oportunidad.

Por su parte, la afinidad de sentido entre lo que asienta Diotima, en torno a la visión de lo bello en sí, lo que finca el Sócrates platónico con la Alegoría

\footnotetext{
8 Platón, Carta VII: 341c-d

9 Platón, República: 511c
} 
de la Línea y lo que Platón registra sin ambages en su Carta VII resulta del todo evidente. Y esa triple referencia permite sustentar que, en el nivel más elevado de su creatividad teórica, el filósofo ha de abrirse al acontecimiento de afrontar lo real absoluto, lo que a su vez permite pensar que, en su grado más alto, la episteme es algo más que el registro proposicional de una adecuación mente-cosa; se trata, más bien, de la experiencia de la verdad absoluta y, finalmente, ese hecho de tanta pregnancia en el plano de la dinámica del alma, esa nóesis, es el hiato que deslinda radicalmente todo saber dóxico (pístico, conjetural, hipotético) y todo saber discursivo (incluyendo el de las ciencias particulares) de la episteme rigurosamente filosófica.

\section{¿Qué es lo que se contempla por medio de la nóesis?}

Está claro que, para Platón, el pensamiento discursivo resulta insuficiente y que, por tanto, los filósofos auténticos no se conforman con los frutos que prodiga. Eso es algo que deja notar la Alegoría de la Línea, al mostrar de manera plástica la necesidad de un nivel de verdad superior al de la dianoética. También lo evidencia - para referir otro ejemplo - la conclusión en que desemboca el largo proceso dialéctico registrado en Teeteto: "resulta que el saber no sería ni percepción ni opinión verdadera ni explicación acompañada de opinión verdadera". ${ }^{10}$ Las expectativas de Platón, en lo que hace a episteme son claramente extremas: la opinión no alcanza el debido nivel epistémico ni siquiera cuando es verdadera, y el discurso explicativo - es decir, dianoético - adolece de la misma limitación, sin que la compañía de algo que habiendo sido descartado - la opinión correcta- pueda darle valía epistémica alguna. En último término, la Alegoría de la Línea ilustra la jerarquía platónica de los saberes: desde lo más bajo y deleznable (el ámbito de la ekaisía, la pistis, la doxa) hasta la visión de lo que realmente es (los dominios de la alétheia, la nóesis, el noûs, la episteme), visiblemente diferenciada de la diánoia: el pensamiento discursivo.

La Alegoría de la Línea muestra de manera plástica tres niveles de verdad. Nada autoriza a verlos como escalones de una rígida ruta ascendente, aunque la combinación entre ellos resulta inevitable en la dinámica espontánea y en la actividad metódica de la razón. La mente humana opera con opiniones,

10 Platón, Teeteto: 210a-b 
conjeturas, creencias, hipótesis, principios lógicos, proposiciones verdaderas e inconsistentes, $\mathrm{y}$, en ciertos casos (y de acuerdo con las doctrinas que Platón deja colar en sus diálogos, esto es lo que distingue al filósofo), también con "teorías", esto es, con "visiones" inmediatas de lo que es en sí. ¿En que se basa esa jerarquía de representaciones? En su sustancioso estudio "Dialéctica, pensamiento 'intuitivo' y 'discursivo' en Platón”, Marcelo E. Boeri (2017) se inclina claramente por el criterio de que tal distinción de grados de acceso al ser se sustenta en la presencia o ausencia de "ingredientes sensibles". Es indiscutible la relevancia de este referente en el pensamiento platónico sobre la dignidad mayor o menor de los saberes. Por lo demás, es del todo atendible el recurso de Boeri a las consideraciones expuestas por Sócrates en diálogo con Simmias, en Fedón (65c y 66b-d), acerca de los obstáculos que opone el cuerpo - máxima concreción de lo sensible - al alma que reflexiona en busca de la verdad (Boeri, 2017: 3). El propio Boeri (2017), no obstante, hacia el final de su artículo, cree necesario matizar el anhelo socrático-platónico (de notorio eco pitagórico) de liberarse del cuerpo a la hora de procurar la verdad, cuando advierte que "ni siquiera en un diálogo como el Fedón, en el cual Platón ve en el cuerpo el impedimento para captar apropiadamente 'lo real' (i.e. la Forma), dice que haya que eliminar el dominio de lo sensible" (22).

Pero, a su vez, se debe tener presente que la base ontológica de lo sensible radica en su relación con el fundamento absoluto de todo ente, que en principio son las realidades eidéticas, las entidades pertenecientes al mundo de lo inteligible. Cabría considerar, entonces, que por encima de las limitaciones epistémicas de las representaciones dóxicas y dianoéticas está su lejanía con respecto a la realidad absoluta que - no sin problemas teóricos que no viene al caso examinar aquí - funda los objetos del mundo; distanciamiento que se traduce en un déficit de ser, tanto de las capacidades y procesos de producción cognitivos cuanto de sus resultados. En último término, esto también es válido para la dialéctica que, tanto en Banquete como en República como en la Carta VII, entre otros textos, aparece como inevitablemente fincada en el ilusorio mundo de lo sensible, pese a que opera como un puente hacia la aprehensión noética.

En definitiva, resulta claro que Platón procura dar razón de tres niveles diferenciados de representación, el más elevado de los cuales (el noético) es cualitativamente diferente de los que le anteceden, porque (de un modo teóricamente muy problemático) conecta con el orden supremo de realidad: el mundo de lo inteligible, ontológicamente distanciado y diferenciado de lo que 
se adscribe al ámbito de lo sensible. De acuerdo con Sócrates, cuando en el libro VI de República explica el significado de las partes de la línea de los saberes, "lo opinable [es decir: lo propio de la doxa] es a lo cognoscible [esto es: 1o relativo a la episteme] como la copia es a aquello de lo que es copiado". ${ }^{11}$ Esta observación socrático-platónica pone de relieve el nexo de los modos y niveles de representación con sus respectivos órdenes de realidad: la doxa se mueve en el terreno del devenir, la episteme en el del ser absoluto.

Por su parte, dado que según indicación expresa en el texto platónico, la diánoia, el pensamiento discursivo, se coloca "en un nivel intermedio entre la opinión y la inteligencia [noûs]", ${ }^{12}$ cabría pensar que aun cuando el discurso, el raciocinio, comporta procesos de elaboración cognitiva suprasensibles y, por ende, conceptos abstractos, no puede acceder al grado epistémico radical de la nóesis, porque tales elementos operan en un plano mimético, imitativo, pues todavía permanecen anclados en los dominios del devenir, en un orden de realidad incidido por el no-ser. En palabras de Sócrates, en la primera sección de la parte de la Línea referida a la episteme, o sea, en el nivel correspondiente al conocimiento dianoético, el alma "usa como imágenes a los objetos que abajo eran imitados y que habían sido conjeturados y estimados como claros respecto de los que eran sus imitaciones". ${ }^{13}$ Conforme con el esquema platónico de "los dos mundos", nada impide pensar que todavía estas imágenes formales de los entes particulares sean, a su turno, mímesis de las entidades eidéticas, imitaciones de sus Ideas de referencia.

A fin de cuentas, podría decirse que la escala jerárquica cognitiva doxa-dianoética-nóesis implica - aunque no se sepa bien cómo- una gradación de estructuras, cada una de las cuales articula una capacidad con determinado objeto de atención, cierto proceso de percepción y/o intelección y la consiguiente representación. Se diría que es la relación de cada uno de esos componentes, en el nivel estructural del caso, con el orden de realidad sujeto al devenir o el de carácter eidético, lo que determina la dignidad mayor o menor de las referidas clases de conocimiento.

Las consideraciones anteriores pueden encuadrar un regreso a la pregunta formulada más arriba, al modo de una leve reformulación de la misma: ¿qué es lo que capta el noûs como resultado de la dialéctica que deriva en nóesis? Existe una larga y rica tradición de serios esfuerzos por responder a

11 Platón, República: 510a

12 Platón, República: 511d

13 Platón, República: 511a 
esta pregunta. No viene al caso sintetizar aquí la muy vasta y variada historia de interpretaciones y elucidaciones a la vera de ese interrogante. A título de ejemplo, se puede traer a colación la respuesta de Francis M. Cornford (1987), en el sentido de que "el objeto de la dialéctica no es establecer proposiciones que adscriban a un predicado a todos los individuos de una clase", sino "la definición de una especie indivisible" (Cornford, 1983: 243). Básicamente, el exégeta inglés combina una razón negativa con otra positiva: 1. 1a dialéctica no procura prodigar contenidos de carácter proposicional sobre determinado objeto y 2. lo que sí ofrecería la dialéctica sería una definición de una forma eidética unitaria. Lo que expresa el enunciado negativo es algo que el propio Platón se empeña en dejar sentado, a saber, la dialéctica implica un modo de discurso, pero sus frutos no tienen carácter discursivo. Por su parte, el segundo enunciado contradice lo establecido en el primero, dado que una definición es, justamente, una de las expresiones del pensamiento dianoético, salvo que se recurra a la noción de "definición" de una manera demasiado carente de rigor. En definitiva, la explicación de Cornford resulta insatisfactoria. A su vez, J. C. B. Gosling (1993) - para echar mano de otro ejemplo- puede afirmar con toda corrección que el conocimiento en Platón es "percepción intelectual de la Forma pertinente" (163), pero nos deja igual de insatisfechos porque en su enunciado el definiens no da cuenta del significado de "percepción intelectual" ni de "Forma", aunque podría decirse que este último caso parece inducirnos a conformarnos con nuestra comprensión discursiva de la doctrina platónica de las Ideas. Igual de limitado luce Mario Vegetti (2012) cuando asienta que "el conocimiento de las ideas se ha de concebir como una intuición intelectual inmediata de carácter extralingüístico, no discursivo" (182). Lo que dice el connotado historiador italiano apenas es una paráfrasis de lo expuesto por Platón.

En general, puestos a responder la pregunta en referencia, los más destacados exégetas de la filosofía de Platón llegan al único punto al que permiten llegar sus diálogos: las Ideas. Quien se apegue al discurso platónico habrá de concluir, llanamente, que 1o captado por el noûs en la nóesis es una entidad de carácter formal, eidético. Pero esa conclusión - en principio, correcta- es una solución demasiado limitada y abre cauce a difíciles problemas colaterales. La noción de Idea o Forma requiere explicación y, por mucho que abundan los intentos en esa dirección, siempre termina siendo una incógnita, un asunto irresuelto. Por ejemplo, Bravo (2002) empieza por dejar sentado que el principal objeto de atención de Platón son "las cosas" y no los discursos 
(104). ${ }^{14}$ Esa acotación permite considerar que la aprehensión inmediata, noética - no discursiva o dianoética - de determinada Idea viene a ser la "visión" directa de una "cosa".

El problema, ahora, es tratar de esclarecer el significado de "cosa". A este respecto, Bravo (2002) estipula, siguiendo a Richard Robinson, el argumento de que "cosa" significa "todo lo que puede ser simbolizado por una sola palabra: toda entidad general o particular, material o espiritual, dependiente o independiente, existente o inexistente, posible o imposible" (104). Esta definición se apega a la prácticamente inabarcable extensión semántica del vocablo "cosa", por lo que su utilidad teórica se antoja bastante limitada. Sin embargo, abre paso al examen de la palabra que, por ejemplo, en el caso de República, nombra lo que capta el noûs: eídos. De entrada, esta voz se caracteriza por una amplia polisemia. Según Bravo (2002), por eídos puede entenderse: "1) 'especie', 'categoría' o 'clase', frecuentemente cercano al de génos, en el sentido de género, 2) [...] 'carácter general', 3) [...] 'idea'” (110). De esto se infiere que el acontecimiento de la nóesis se cifra en la aprehensión inmediata de determinada Idea. Pero esta conclusión presenta, al menos, dos inconvenientes: no se desapega de lo establecido en el propio discurso platónico (la visión noética aprehende Ideas, Formas) y, en apego a la argumentación de Bravo, no muestra con claridad la condición de "cosa" de una forma eidética.

En la ruta exegética trazada por Bravo, se diría que, si la Idea platónica es "cosa", viene al caso "sustancializar" al ente eidético. Un repaso riguroso de las obras de Platón y el constante diálogo con intérpretes connotados le permiten a Bravo poner de relieve las afinidades semánticas existentes entre las palabras ousía y eídos. En cercanía con W. K. C. Guthrie, verifica que "Sócrates y Platón conciben ousía como un eídos o también como una idéa". Un rastreo del uso platónico de la voz ousía, desde Eutifrón hasta Leyes, le permite asentar que ousía es la "naturaleza permanente que las cosas tienen por sí mismas" (Bravo, 2002: 106). Puede convenirse, entonces, en que "ousía es la esencia o naturaleza de una cosa" (Bravo, 2002: 107), lo que puede traducirse en términos de que la Idea, el referente eidético de tal cosa, es ousía. A esto Bravo agrega consideraciones como las de A.E. Taylor y J. Burnet, por las cuales se concluye que, al hablar de ousía, Platón asumía la tradición jonia y/o pitagórica, para la que esa voz connotaba: "1) El sentido de existencia o realidad, cercano al de ón, 2) el de esencia o naturaleza, cercano al de phýsis, 3) el de ser o sustancia" (Bravo,

\footnotetext{
14 "lo que fundamentalmente estudia Platón no son las palabras, sino las cosas" (Bravo, 2012: 104).
} 
2002: 115). De la amplia y puntual exploración histórico-filológica de Bravo derivan, cuando menos, estos resultados: 1) las nociones de ousía y eídos son coextensivas, puesto que nombran la misma cosa, y 2) cuando se recurre a cualesquiera de los dos nombres, se habla de "carácter general, especie y forma" (Bravo, 2002: 115), pero también de entidad sustancial, realidad esencial y aun de phýsis.

Llegados a este punto, se advierte que, en el proceso de nóesis, el noûs capta determinada Idea, cierta realidad sustancial-esencial suprasensible, que no es un concepto abstracto de los que intervienen en la dinámica del pensamiento discursivo. Se diría, pues, que la aprehensión directa de las Ideas viene a ser el resultado de la labor dialéctica efectivamente desempeñada. Pero, aun cuando esto es teóricamente sostenible, también lo es el hecho de que Platón no facilita las certezas plenas, cuando se trata de asuntos de complejidad comprobada. No debe asombrar, entonces, que en la misma República, aunque a bastante distancia de lo asentado en la Alegoría de la Línea, Sócrates invite a Glaucón a dialogar sobre la mímesis "por medio del método acostumbrado", esto es, aquel que consiste en "postular una Idea única para cada multiplicidad de cosas a las que damos el mismo nombre". ${ }^{15}$ Esto puede entenderse en los términos de que la nóesis está también en el arranque de la diánoia, ya que, aun cuando la dialéctica es el camino a la aprehensión noética de lo que realmente es, en tanto que método dialógico, en su despliegue, antes de alcanzar su resultado final como nóema, tiene un carácter discursivo.

Esto es algo que, entre otros, ha observado bien Marcelo D. Boeri (2017), como se evidencia cuando afirma que "ni la nóesis es una captación intelectual misteriosa de las esencias platónicas ni la diánoia puede entenderse en un sentido puramente proposicional independientemente de la nóesis" (21). En el caso de Boeri, esta conclusión conecta con una interpretación de algunos pasajes de la Alegoría de la Línea que comparte con Franco Trabattoni. En 1o esencial, opina que los contenidos con que operan tanto el pensamiento discursivo como la captación inmediata de lo real son las Formas. En sus propias palabras: "Los objetos de la diánoia y la nóesis son los mismos: Formas o Ideas" (Boeri, 2017: 2). Pese a que es el propio Platón quien la propicia, esa afirmación no está libre de problemas exegéticos. ¿Es en efecto idéntica la Idea que opera casi como axioma que da cauce a un proceso dialéctico -incluso uno dianoético- y la Idea aprehendida por el noûs, al término del mismo? Los textos

15 Platón, República: 596a 
platónicos del caso no ayudan a articular una respuesta definitiva a esa pregunta. El postulado de las Formas es todo menos unívoco, teóricamente terso y homogéneo. Los diálogos de Platón, por sí solos, aun cuando puedan ofrecer pistas de notable relevancia, resultan insuficientes, a la hora de forjarse una idea sustentable del mundo de lo inteligible.

No es el momento para incoar aquí un debate sobre las doctrinas no escritas (ágrapha dógmata) de Platón, pero es del todo lícito advertir que estas permiten enriquecer, de manera decisiva, las de por sí difíciles representaciones del platónico mundo de lo inteligible. Sin necesidad de ir más lejos, las rigurosas investigaciones de la Escuela de Tubinga y la de Milán han puesto de relieve que dicho ámbito ontológico 1) no está integrado sólo por las Ideas replicadas por las cosas sensibles (mímesis) o de las que "participan" éstas (méthexis); 2) las Ideas no se sitúan en el nivel más elevado de realidad (lo que "limita" - por decirlo de un modo claramente problemático- su presunta absolutez); y 3) por encima de las Ideas, en dotación de ser - de hecho, con una condición rigurosamente absoluta-, están los Principios (el Uno y la Díada Indeterminada) y los Números Ideales.

Tener en cuenta las referidas doctrinas intra-académicas comporta colocar la nóesis en un nivel diferente al que, en general, le asigna el discurso textual platónico. ¿Podría pensarse que, tras las condiciones anímicas y lógicas necesarias inherentes al ejercicio de la dialéctica, el noûs capta solo Ideas o también las cifras de la idealidad que estructura lo real o los propios principios o combinaciones de algunos de estos elementos o el conjunto de ellos? Habituados como estamos al límite de los diálogos de Platón, las implicaciones de esta pregunta pueden resultar exageradas; pero nada impide pensar en la posibilidad de que la nóesis, la captación inmediata y unitaria de lo real, abarca todos esos componentes que Platón y algunos de sus adeptos sólo pueden referir de manera analítica. Las doctrinas platónicas no escritas imponen una insoslayable cautela ante los alcances ontológicos que los diálogos parecen asignar a las Ideas. Pero eso no significa la inexistencia de ciertas presencias en el discurso textual platónico que también inducen a esa reserva; presencias que, por lo demás, operan como señales implícitas del peso y el relieve teórico de las enseñanzas intra-académicas, de cara a lo expuesto en los diálogos.

La manera en que Sócrates argumenta, junto con Glaucón, en torno a la idea de Bien en sí, en la Alegoría del Sol (libro VI de República), luce como referencia asaz ilustrativa de 1o que es una Forma adscrita al ámbito de 1o inteligible, en contraste con representaciones abstractas - que, a su modo y en 
algún grado, también son Formas - de una episteme que sólo puede tener carácter discursivo, dianoético. Después de establecer que el sol viene a ser "el vástago" del Bien absoluto, el filósofo detalla la analogía entre los nexos de la luz solar con las operaciones de la visión sensible y sus resultados, por una parte, y los vínculos de la Idea de Bien con "la inteligencia y lo que intelige", por la otra. ${ }^{16}$ Ya en esa parte del símil platónico se observa sin ambages una disyunción entre una Idea (la del Bien), que además de actuar como referente eidético de todo lo bueno sensible opera como condición causal del propio noûs y de lo que este produce. Eso ya supone un fuerte obstáculo para los intentos de identificar las Ideas "reales" (como las entendía el realismo medieval) de las representaciones conceptuales con las que opera cualquier modo de proceso discursivo, por muy consistente y verdadero que sea. Pero Platón agrega otro reparo de carácter ontológico a la pretensión de que en todos los niveles de actividad epistemológica las Ideas son iguales, cuando asienta que "a las cosas cognoscibles les viene del Bien no solo el ser conocidas, sino también de él les llega el existir y la esencia, aunque el Bien no sea esencia, sino algo que se eleva más allá de la esencia, en cuanto a dignidad y potencia". ${ }^{17}$

En apego al discurso platónico, se puede pensar que 1) hay una jerarquía entre las propias Ideas; 2) la de Bien es una Idea que ocupa un lugar prominente en ese orden; 3) hay al menos una Idea de la que procede nada menos que la esencia, la existencia y la cognoscibilidad de lo cognoscible; y 4) esa especie de Idea suprema se sitúa más allá de la esencia; lo que cabría entender en el sentido de que su ámbito ontológico es el de la idealidad pura, ajena a toda determinación de la dinámica del devenir, como corresponde al ser absoluto. De ninguno de estos aspectos puede desprenderse el argumento de que las formas operantes en procesos discursivos son equivalentes a las que apuntan los de carácter noético. No basta con que en ambos casos se trate de Formas, para concluir que se trata de entidades de la misma significación ontológica.

En su rigurosa argumentación, Boeri apela al manejo de las Formas que Platón reconoce en los geómetras, para ensayar una afinidad con las Ideas de lo Bello y el Bien a las que se refiere Sócrates en varios pasajes de República. Boeri (2017) propone una especie de distinción accidental entre "Formas matemáticas" - o, más generalmente, "Formas descriptivas" -, como "cuadrado"

16 Platón, República: 508b-c

17 Platón, República: 508b-c 
y “diagonal”, y "Formas evaluativas, como 'bello', 'bueno' o 'justo'”. Según su criterio, en general, las primeras serían las que intervienen en los procesos dianoéticos y las segundas, las que se avienen con la nóesis (Boeri, 2017: 9). Pese a ser del todo atendible, ese argumento trasluce, al menos, estos inconvenientes. Por un lado, estipula una identidad ontológico-epistemológica no probada - ni autorizada por el texto platónico, como se ha visto- entre las formalizaciones en que se sustentan ciencias como la geometría en sus procesos heurísticos y los contenidos captados por el noûs en su desempeño noético. Por el otro, y en consecuencia, si bien puede aceptarse la consideración de Boeri en el sentido de que la diánoia no podría operar sin un componente noético y la nóesis tampoco sin el recurso a elementos discursivos inherentes a la dialéctica, también debe tenerse en cuenta que las intuiciones empíricas y la generación primaria de anticipaciones universales no pueden compararse con la aprehensión directa, intencional y "sustancial" de entidades como las Formas modélicas, los Números Ideales o los Principios. Aun cuando el texto de República no esclarece con precisión lo que debe entenderse por "principio" (arché), no es desdeñable la frecuencia con que esa palabra aparece en él. Sobre todo, exige poner mayor atención en ese vocablo, al margen de la postura de cada lector en torno a la significación y utilidad de las doctrinas platónicas no escritas. Esto, porque en ello parece cifrarse la comprensión del hiato ontológico-epistemológico que separa el orden de 1o dianoético del de lo noético. Acaso no esté de más traer a colación el archiconocido pasaje, en el que Sócrates describe la dialéctica como "el método" que "marcha, cancelando todos los supuestos, hasta el principio mismo". ${ }^{18}$ Y la importancia de ese movimiento heurístico luce mucho más claramente apreciable, cuando se tiene en cuenta que el procedimiento dialéctico viene a ser clave en la superación de las limitaciones epistémicas de las ciencias que, como la geometría, solo "captan algo de lo que es" y, a lo más, "nos hacen ver lo que es como en sueños". ${ }^{19}$

Con caracterizaciones como ésa, Platón asienta con fuerza la idea de que la "episteme dianoética" es, en el fondo, falsa episteme, porque permanece anclada en un orden ilusorio de realidad por mucho que opere con contenidos óntico-epistémicos más dignos que los de las representaciones dóxicas. Esto marca una distinción cualitativa insuperable entre la diánoia y la nóesis.

18 Platón, República: 533c-d

19 Platón, República: 533b 
También impele a desestimar todo posible gradualismo en la ruta hacia la verdad absoluta; es decir, no halla sustento estimable el planteamiento de que los conocimientos dianoéticos sean una condición de necesidad del acontecimiento final de la verdad absoluta. Así que, el propio texto platónico ofrece bases suficientes para considerar que los contenidos a los que conduce el proceso dialéctico-noético están marcados por una diferencia ontológica infranqueable con respecto a las representaciones abstraídas por la razón en su uso teórico.

A partir de lo expuesto en los párrafos anteriores, se colige que, en primer lugar, la diánoia y la nóesis son recíprocamente irreductibles, pues ambas remiten a órdenes esencialmente distintos de realidad sin menoscabo de los vasos comunicantes que se puedan tramar entre ellos. En segundo lugar, la episteme noética es un evento raigalmente extradiscursivo, aunque puede tener fuertes nexos con una modalidad sui generis de proceso discursivo: 1a dialéctica. ${ }^{20}$ Por lo demás, en tanto que diálogo vivo que puede anteceder el evento noético, da a entender implícitamente que la nóesis no puede advenir a resultas de la interpretación de discursos escritos. En tercer lugar, dado que acontece al margen del despliegue lógico inherente a toda actividad dianoética, la nóesis se da como resultado de un "salto" supradiscursivo: la superación de un sistema de mediaciones lógico-heurísticas, en favor del instante inmediato de la "visión" de lo que es en sí, hecho que tiene un carácter "lógico", en la medida en que opera conforme a determinada conexión con el lógos-noûs, aunque se da con independencia de los sistemas de reglas para el uso teórico-discursivo de la razón, de lo cual se desprende que el acontecimiento noético es una experiencia (aspecto que se explicará más adelante). A su vez, dado el carácter experiencial de la aprehensión inmediata de lo real, la verdad noética es "inefable", imposible de comunicar por medio del lenguaje, explicando con ello que el resultado del proceso noético — sea cual sea; apenas nombrado con locuciones como "ser en sí", "lo que es", "verdad absoluta" y afines-, pese a que se le asuma como la razón de ser de la filosofía, no pueda traducirse en algo como una escritura genuinamente filosófica; de ahí la conciencia socrático-platónica de que "la filosofía no se escribe" o de que, en rigor, "no puede haber libros de filosofía", como advierte el propio Platón en la Carta VII:

20 También habría que considerar las "ciencias" que "auxilian" la labor dialéctica, según lo establecido en República (533d). Pero aquí se concentra el foco en la condición lógico-verbal del proceso dialéctico, como momento previo a la superación de ese carácter discursivo, en virtud de un "salto" que deja atrás o interrumpe toda ilación inferencial o deductiva. 
"cualquier persona seria se cuidará muy mucho de confiar por escrito cuestiones tan serias" como la captación directa de lo absolutamente real. ${ }^{21}$

\section{La experiencia de la episteme noética}

No se necesita una perspicacia especial para advertir que, en términos generales, el socratismo platónico recurre a las referencias de la luz y la visión para efectuar la difícil tarea de verbalizar y dar cuenta de lo que resulta de los procesos heurísticos. Esa característica del discurso platónico puede estar expresando de manera implícita, al menos, que la theoría (la contemplación inmediata y momentánea) de lo que es en sí, se adscribe al amplio universo de la experiencia humana, y que, en virtud de su carácter experiencial, la genuina theoría no puede ser comunicada de manera directa, por lo que el filósofo que se proponga hablar de ella deberá acudir a un discurso indirecto, en general, unido por una metafórica de la luz y la vista. De ahí que, como precisa Vegetti (2012), cuando el texto platónico refiere los frutos de la razón dialéctica, más allá de sus componentes de cariz lógico-discursivo, se trata de "un acto de pensamiento (nóesis) que tiene su correspondencia con el acto de la visión" (182). Sí, el acontecimiento de la verdad puede describirse como un acto - al modo en que lo hace Vegetti- y aun cuando, en su condición de evento único e instantáneo, resulte indefinible (imposible de adscribir a ningún género ni especie, a la manera de los objetos singulares), puede ser "demarcado" o determinado, con base en el registro de ciertos rasgos colaterales con los que se presenta. Entre esos rasgos, se observa el de la inmediatez. Ya en la primera sección de este escrito se pone de relieve la singular paradoja de la dialéctica: un sistema procesual de diálogo y raciocinio inevitablemente discursivo, que sin embargo deviene nóema, es decir, captación extratemporal de lo que es en sí. La vía a la episteme absoluta se sujeta, en principio, a las determinaciones del tiempo, el espacio y la necesidad lógica, pero la meta hacia la que se endereza y en la que finalmente desemboca se coloca más allá de toda determinación. El símil de la "chispa", que refiere Platón en su Carta VII, para dar razón de este acontecimiento, ilustra

21 Platón, Carta VII: 344c 
con notable plasticidad esa idea del "salto noético". ${ }^{22}$ Ese momento de discontinuidad comporta la superación de las mediaciones que lo hicieron posible.

También se ha señalado más arriba el punto de la subitaneidad del acceso a la episteme noética. Es claro que se trata de uno de los signos distintivos del acontecimiento noético. A lo ya expuesto a este respecto, cabría agregar la consideración de que el suceso repentino de aprehender directamente el ser absoluto parece incluir un momento de ignorancia o falta de control consciente de la etapa final del proceso racional prenoético. Caracterizar como repentino un acontecimiento que se da en un momento determinado de dicho proceso equivale a reconocer que ha sucedido sin que se sepa por qué. Aquí, subitaneidad comporta ignorancia, una cesura en la ilación lógica del discurso prenoético. El registro verbal de un evento de esa clase impone el recurso deliberado a la expresión alegórica. Acaso podamos medio entendernos, si decimos que se trata de algo como un "cortocircuito" de la razón que procura con denuedo la verdad última: algo que, bajo ciertas condiciones, se aviene con el orden supremo de realidad y provoca que la razón humana rebase sus límites ordinarios. Si no se puede hablar con fundamento de ese instante de "salto repentino" de la diánoia a la nóesis, es porque el alma o agente de conocimiento se sale del flujo procesual-racional - lo que equivale a un no-saber-, y ese desborde de un dominio, de una manera inexplicada por "inefable", coincide con una incursión del alma en el reino de lo real absoluto.

Lo anterior no alcanza a negar la raigal inteligibilidad del nóema. Se diría que el proceso noético, visto en su conjunto, integra con efectividad teórica la tantas veces referida fase racional-discursiva, esto es, la etapa de actividad dialéctica, regida por la aplicación sistemática de reglas lógicas, con el momento de su "superación" en términos de "salto noético", que resulta en intelección, producción heurística, conocimiento absolutamente verdadero y captación de lo real al modo de una entidad objetiva, que por simple conveniencia técnica debemos conformarnos con designar con la voz nóema. Puesto en la ruta de la dialéctica, de manera disciplinada y movido por el fervor erótico-heurístico inherente a la auténtica filosofía, el acontecimiento noético sobreviene en el alma de "aquel que trata con lo que es y lo invisible". ${ }^{23}$ Claro está, "invisible" (to aóraton) debe entenderse aquí como "no-sensible", como "imposible de ver con los ojos de la cara", en fin, como "inteligible".

22 En la primera sección de este texto, concretamente en el lugar al que remite la nota 7, se reproduce la enunciación platónica del referido símil.

23 Platón, República: 529b 
Por lo demás, en el discurso platónico, la inteligibilidad de lo que es conecta $-\mathrm{y}$ aun se identifica - con su cognoscibilidad. Sócrates aclara sin ambages en República que "lo que es plenamente es plenamente cognoscible, mientras que lo que no es no es cognoscible en ningún sentido". ${ }^{24}$ Se entiende que los procesos gnoseológicos relativos al mundo del devenir se ven lastrados por un infranqueable límite epistemológico, determinado por el orden de realidad al que remiten. El alcance heurístico de los saberes está condicionado por el ser al que remiten. Las representaciones (doxa, eikasía, pistis) en torno a lo dado en el mundo de lo sensible nunca alcanzarán el estatus de verdaderos conocimientos, porque dan cuenta de manera confusa y oscura de un mundo que también tiene esas características. Al contrario, la intelección de lo que es en sí es alétheia en su máxima expresión: saber absoluto de lo real absoluto.

En congruencia con lo anterior, esa experiencia del saber plenamente verdadero comporta la máxima claridad alcanzable por un conocimiento. El asunto de la claridad de la representación tiene un gran relieve en el pensamiento socrático-platónico. En último término, la experiencia de la verdad puede entenderse como un dejar atrás las visiones ilusorias - en general, del tipo de las que acontecen en la fantasiosa atmósfera de la caverna- para conectar el alma con lo real tal como genuinamente es. Los diversos niveles de representación - los de cariz dóxico y conjetural, los de carácter dianoético y los de naturaleza noética - implican grados diferenciados de claridad con respecto a lo real. La relación de Diotima acerca de la ascensión del alma por la ruta de la dialéctica, así como la jerarquización epistémica inherente a la Alegoría de la Línea, dan cuenta de una elevación desde visiones turbias, confusas, borrosas, oscuras de cosas que se dan también con esas características, hasta la contemplación pura e impoluta de lo que, asimismo, es límpido e inmaculado. Las diversas posibilidades del método dialéctico contribuyen al cumplimiento de ese literalmente extra-ordinario evento. De ahí que, una vez más, según Sócrates, "lo que de real e inteligible es estudiado por la ciencia dialéctica [...] es más claro" que lo investigado por las ciencias discursivas. ${ }^{25}$

Esa claridad de la visión noética se experimenta, además, con una intensidad fuera de lo común. El registro platónico de esa experiencia aparece con nitidez admirable en la Carta VII: "Y cuando [...] se han hecho poner en relación unos con otros cada uno de los distintos elementos, nombres y definicio-

\footnotetext{
24 Platón, República: 477a
}

25 Platón, República: 511c 
nes, percepciones de la vista y de los demás sentidos, cuando son sometidos a críticas benévolas, en las que no hay mala intención al hacer las preguntas ni respuestas, surge de repente la intelección y comprensión de cada objeto con toda la intensidad de que es capaz la fuerza humana". ${ }^{26}$ Se percibe, en estas líneas, la conciencia platónica de la endeblez (no sólo la turbiedad) de las representaciones sensibles, en comparación con la impactante vivacidad de la súbita aprehensión de la realidad de fondo de lo investigado. Como se adelantó en la segunda sección de este escrito, es la dignidad ontológica del objeto contemplado, en correspondencia con la disposición adecuada del alma que contempla, lo que puede explicar el evento noético. Thomas A. Szlezák (2019) agrega a esa consideración un elemento afín, de notable relevancia: para Platón - de acuerdo con aclaraciones que expone, por cierto, en la Carta VII- "el mundo de las Ideas [...] es divino (theion)", y "sus principios más elevados son necesariamente divinos en el más alto grado" (62).

Dado que hay elementos suficientes para considerar que el nóema se adscribe al ámbito de lo absolutamente real y divino, con lo que se coloca en un plano que rebasa los límites del mundo del devenir, y supuesto también que se trata de un evento que requiere un alma dispuesta de manera apropiada, cabe inferir que la verdad noética viene a ser la máxima expresión de una adaequatio intellectus ad rem. No sería erróneo fijarse en la afinidad de esa perfecta interconexión óntico-epistémica con el modelo que, a ese respecto, estipula Sócrates en Fedón. En uno de los momentos más intensos del justamente célebre pasaje de ese diálogo, sobre la conveniencia de que el alma se separe al máximo del cuerpo, a fin de poder ejercer la filosofía de la mejor manera posible, el filósofo dice a su interlocutor Simmias que un estado tal supone que "estaremos en compañía de lo semejante", lo que asimismo implica que "conoceremos por nosotros mismos todo lo puro, que eso es seguramente lo verdadero". ${ }^{27}$

Subitaneidad, inmediatez, eventualidad, inteligibilidad, cognoscibilidad, divinidad, claridad, intensidad, aparecen todas en el discurso platónico, según se ha visto, como atributos concernientes al proceso noético tanto en su despliegue y concreción como en su resultado (el nóema). Tales nociones conforman una suerte de red conceptual que trata de dar cuenta de un evento

26 Platón, Carta VII: 344b-c

27 Platón, Fedón: 67a-b 
inefable a la par de experimentable por el alma humana en condiciones adecuadas a tal fin.

Ciertamente, la nóesis es una experiencia. Son conocidos los problemas teóricos que comporta la noción de "experiencia". No será este el lugar donde se atiendan. Tampoco viene al caso detenerse aquí en la variada gama de doctrinas sobre la experiencia, registradas por la tradición filosófica. Para los propósitos de este escrito, bastará con estipular como "experiencia" el evento anímico asociado a la representación de determinado objeto, de manera tal que ocasiona una literal alteración -conversión en algo otro respecto de 1o que venía siendo- del alma cognoscente. En términos concretos, se entiende aquí por "experiencia" el acontecimiento en razón del cual un conocimiento significativo dota al alma que conoce de una potencia epistémica mayor -1o que, a su vez, implica una capacidad más efectiva de comprensión de la realidad- y un fortalecimiento de sus disposiciones de carácter técnico y ético.

La aprehensión directa del objeto eidético - el cumplimiento del nóemaresulta del encuentro entre un alma bien dispuesta a tal propósito y un objeto, no sólo presente ante ella, sino propiciador del acontecimiento en referencia. Ya se ha visto cómo, para Platón, por ejemplo, la idea de Bien es la fuente de la cognoscibilidad de lo cognoscible. ${ }^{28}$ Puesto que el proceso noético confirma que las Ideas son las únicas entidades abiertas al acontecer de un verdadero conocimiento, y la idea concreta de Bien es reconocida expresamente (en República) como modelo de las Formas - es decir, como modelo de modelos-, resulta pertinente proyectar en cualquier Idea la potencia generadora de episteme que se le reconoce a la de Bien. Esto puede entenderse, razonablemente, como un proceso de afección de las realidades eidéticas sobre el alma cognoscente, pero ello no obsta para que esta desempeñe siempre una función activa, incluso desde antes de la labor dialéctica y más marcadamente cuando se emprende ésta. En la experiencia de la verdad noética, el alma aprehende - apresa y adopta - un objeto noemático de manera completa, unitaria (no parcial ni fragmentada) y, como se adelantó en su momento, ello genera un efecto -lo propiamente experiencial- en el alma cognoscente. No es disparatado considerar que Sócrates, en República, está pensando en algo así, cuando implícitamente da por hecho que filósofo es quien tiene "experiencia de la verdad" (apeiroi aletheías) y, por ello, es capaz de distinguir "lo que es

\footnotetext{
${ }^{28}$ Una vez más, en la segunda sección de este escrito.
} 
verdaderamente arriba, abajo y en el medio", como adverbios que refieren todas las regiones de la realidad, desde la más deleznable hasta la más digna. ${ }^{29}$

Tampoco está fuera de lugar considerar que la idea socrático-platónica de la verdad como experiencia tiene una apreciable conexión con el símil del conocer como impronta en la tablilla de cera que sería el alma cognoscente. En Teeteto, Sócrates pide cortésmente a su interlocutor, cuyo nombre titula el diálogo: "Concédeme [...] que hay en nuestras almas una tablilla de cera, la cual es mayor en unas personas y menor en otras, y cuya cera es más pura en unos casos y más impura en otros, de la misma manera que es más dura unas veces y más blanda otras, pero que en algunos individuos tiene la consistencia adecuada". ${ }^{30}$ Es razonable pensar que, para el filósofo, el alma es una potencia vocada a la experiencia, es decir, una disposición a producir representaciones de determinados objetos, figuraciones de valor epistémico, dotadas de una densidad rayana en lo icónico. Tales "imágenes" se sedimentan en el alma, alegorizada como plataforma hecha a base del material maleable por excelencia en la Antigüedad, la cera de abejas, cuya calidad depende de las cualidades que presente en ellas esta sustancia (pureza, cantidad, solidez, etcétera), de modo que a mejor calidad de esa "cera anímica", mayor dignidad de los resultados epistémicos que obtiene y retiene.

La noción de experiencia aquí estipulada implica, necesariamente, la figuración del alma - nombre genérico del agente productor de representacionescomo disposición en constante movimiento creador y constructor. En la dinámica de esa potencia representadora, el acontecimiento de cada nuevo resultado epistémico es, justamente, experiencia. La impronta que deja ésta en el alma -týposis, en un léxico caro a los estoicos - viene a ser confirmación y sello más o menos perenne de toda genuina experiencia. De ahí el nexo que Sócrates descubre entre la intensidad de la experiencia y las operaciones de la memoria. ${ }^{31}$ Pero, junto a todo eso, cabe considerar que la alusión socrática

29 Platón, República: 584e

30 Platón, Teeteto: $191 \mathrm{c}-\mathrm{d}$

31 Platón, Teeteto: 191d. En otro pasaje del mismo diálogo, Sócrates abunda en sugerentes precisiones sobre la impronta epistémica en la tablilla de cera anímica. "[...] cuando la cera [arguye el filósofo] es, en el alma, profunda, abundante y lisa y tiene la adecuada contextura, lo que llega a través de las percepciones se graba en ese 'corazón' del alma, al que Homero llamó así para aludir a su semejanza con la cera. En las almas de tal naturaleza, las señales se hacen nítidas y tienen la suficiente profundidad como para llegar a ser duraderas. Esas personas, en primer lugar, poseen facilidad para aprender, tienen además buena memoria y, finalmente, no invierten la posición de las señales en relación con las percepciones, sino que sus opiniones son verdaderas. En efecto, al ser las señales nítidas y espaciadas, las refieren rápidamente a las impresiones correspondientes, que son precisamente las que denominamos cosas reales, de la misma manera que reservamos el nombre de sabios para esta clase de personas" ( 
a la "consistencia adecuada" de la cera del alma remite a su capacidad de generar las condiciones aptas para desplegar la nóesis y efectuar el nóema: concretamente, la experiencia de la verdad en su grado más elevado.

Los procesos considerados hasta aquí requieren por fuerza ciertas condiciones para su realización. No cualquiera ni en cualquier ocasión ni por un simple acto de voluntad puede vivir la experiencia de la verdad noética. Para que esto suceda, se necesita contar con determinadas potencias y aptitudes, que en sus manifestaciones más excelsas tienen el rango de virtudes. Lo deja sentado Sócrates, sin ambages, cuando advierte a Glaucón que "el poder dialéctico sólo se revelará a aquel que sea experto en los estudios [estrictamente filosóficos] y que cualquier otro es incapaz", razón por la cual el filósofo le aclara a su interlocutor sobre que "ya no serás capaz de seguirme". ${ }^{32}$

Las disposiciones favorables a la filosofía genuina, en general y en principio, son phýsis - es decir, proceden directamente de la naturaleza-, pero también se forman por medio de una esmerada y persistente labor educativa. Así, pues, en la filosofía socrático-platónica, el auténtico filósofo conjuga capacidades naturales (como un grado considerable de inteligencia, una memoria efectiva, una capacidad notable de articulación de la palabra, un talento estimable para concebir y asociar conceptos abstractos, aptitud para el examen sinóptico de situaciones y acontecimientos, una pulsión erótica dirigible hacia la theoría y, en todo momento, un ánimo propenso a la verdad, una edad adecuada, inclinaciones vocacionales a tono con los actos y procesos implicados en la tarea de pensar) con lo que aportan las actividades de entrenamiento teórico, las actitudes de renuncia ascética, de afirmación psíquico-ética y de consolidación de tales disposiciones. Por lo demás, junto a estas facultades naturales-culturales, la acción especulativa, noética, comporta una gama de factores procedimentales que acondicionan el alma del pensador para que aquellas operen de la mejor manera. En este segundo campo entran aspectos como la investigación dialéctica, la purificación del alma, la familiaridad con los asuntos examinados, la identificación o paridad alma-objeto, el recurso prudente a una "heurística simposíaca" y opciones afines. En resumen, virtudes intelectuales

Platón, Teeteto: 194c-d). Por su parte, en su Carta VII, en medio de alegatos sobre la imposibilidad de transmitir por escrito las verdades a la que permite acceder la genuina filosofía, Platón sostiene que no es necesario transcribirlas (ni viene al caso leer lo que se diga de ellas), porque "no hay peligro de que se olviden, una vez que han penetrado en el alma" (Platón, Carta VII: 344d-e).

32 Platón, República: 533a 
y morales, así como procedimientos para su mejor despliegue, su constante afirmación y consolidación, su mayor efectividad heurística y práctica.

En el discurso platónico, menudean las precisiones sobre las disposiciones que caracterizan al auténtico filósofo. Sería prolijo en exceso registrarlas y examinarlas aquí. Este pasaje de República compendia, en buena medida, la idea socrático-platónica a ese respecto: la filosofía es, para Sócrates, "una ocupación que no se puede practicar como es debido, si no se está por naturaleza dotado de memoria, facilidad para aprender, grandeza de espíritu y de gracia y no se es amigo y congénere de la verdad de la justicia, de la valentía y de la moderación". ${ }^{33}$ Más allá de ese cuadro genérico y a título de ilustración, será suficiente con considerar dos aspectos, uno predominantemente natural - la edad adecuada para ejercer la dialéctica- y otro más propiamente cultural-educativo - el sentido de totalidad o capacidad sinóptica ante lo que acontece-.

Según el Sócrates platónico, la edad influye de manera decisiva en el buen ejercicio de la filosofía y en las responsabilidades ético-políticas que ello implica. Claro está, no se trata de reivindicar la mera acumulación de años de vida, como supuesta garantía de virtudes éticas e intelectuales ni, por tanto, de una mejor aptitud para la genuina vida filosófica. Sólo si se da como la ocasión para moldear, educar y desarrollar tales disposiciones, de manera excelente, la edad adquiere la valía que se le adjudica en la filosofía platónica. En consecuencia, la edad apropiada no es una condición puramente natural para la buena praxis filosófica. Se trata de la conjunción de naturaleza con educación. Es necesario esperar a que quien tenga dotes naturales para la filosofía se forme de manera adecuada durante un tiempo prolongado. Como esa formación se alarga por décadas, sucede que quien se beneficia de ella necesariamente termina acumulando años de existencia. Se entiende, entonces, por qué Sócrates exige la precaución de alejar la dialéctica de los jóvenes, pues cuando éstos "gustan por primera vez las discusiones, las practican indebidamente convirtiéndolas en juegos e, imitando a los que los han refutado a ellos, refutan a otros, gozando como cachorros de tironear y dar dentelladas con argumentos, a los que en cualquier momento se les acercan". ${ }^{34}$ Además, según el filósofo, ese "mal juego dialéctico" termina sumiendo a los jóvenes que lo practican en el escepticismo, lo que ocasiona secuelas graves en las siempre difíciles relaciones entre filosofía y sociedad. ${ }^{35}$

33 Platón, República: 487a.

34 Platón, República: 539b

35 Platón, República: 539b-c 
Según lo que se asienta en República, aproximadamente a los 50 años de edad, tras haber "salido airosos de las pruebas", será probable que las personas volcadas a la filosofía estén en la disposición adecuada para afrontar los procesos que las lleven a la experiencia de la verdad noética. ${ }^{36}$ Se advierte, sin mucho esfuerzo, que la edad aparece en el discurso platónico como una condición -en principio, natural, pero reforzada por una adecuada formación teórica, técnica y ética - para el acceso a la más radical episteme. Y dado que, en el caso de Platón, la filosofía no puede disociarse de la política, cae de suyo que en el referido diálogo Sócrates asiente que "los justos, una vez avanzados en edad, detenten el mando de los Estados". ${ }^{37}$ No se pierda de vista que, en ese pasaje, "justos" (dikaioi) es sinónimo de "filósofos". Por su parte, el sentido de totalidad inherente al filósofo verdadero, la tendencia a colocar cada objeto de interés teórico en un panorama de conjunto, aparece en el discurso platónico como una disposición adquirida en el despliegue riguroso y sostenido de la praxis filosófica. Desde luego, también esa facultad o virtud remite por fuerza a una dimensión natural condicionante, aunque no predomine sobre el elemento resultante del esfuerzo formativo sistemático. Así que se trata, al contrario del caso de la edad (natural-cultural), de una potencia cultural-natural. De acuerdo, de nuevo, con Sócrates, cuando los jóvenes en proceso de formación - rondando los 20 años de edad-dejen atrás la "gimnasia obligatoria", se escogerá y se inducirá adecuadamente a los que puedan superar los conocimientos dispersos que han recibido, desde su niñez, a articular "una visión sinóptica de las afinidades de los estudios entre sí y de la naturaleza de lo que es". ${ }^{38}$ Glaucón, en su papel de interlocutor del filósofo en ese momento, asiente en cuanto a que esa es la educación que en verdad distingue y constituye a quien aspira a la vida filosófica. Asentimiento que aprovechará Sócrates para dejar por sentado que esa es "la más grande prueba de la naturaleza dialéctica y de la que no es dialéctico; pues el dialéctico es sinóptico, no así el que no lo es". ${ }^{39}$ Esto, claro está, en el entendido de que el término "dialéctico sinóptico" (synoptikos dialektikós) nombra y caracteriza al filósofo en la mejor disposición esperable para la experiencia noética.

Las disposiciones naturales hacia la verdad noética operan concretamente en conjunción con prácticas y procedimientos ad hoc. En general, se trata de

\footnotetext{
36 Platón, República: 540a-b

37 Platón, República: $613 \mathrm{~d}$

38 Platón, República: 537c

39 Platón, República: 537b-c
} 
factores de acondicionamiento del proceso noético. En República, Platón remacha sobre la insoslayable necesidad de esforzarse con miras a alcanzar la preparación adecuada para el ejercicio de la genuina filosofía. Si bien esto es algo que se infiere desde el momento en que se examina la dilatada longitud de "currículum" de educación filosófica propuesto en dicho diálogo, no por ello se deja de señalar en él, de manera precisa, la ascética que precede, posibilita y acompaña a la praxis filosófica. Por ejemplo, cuando Sócrates le aclara a Adimanto que "es el circuito más largo el que debe recorrer [el filósofo] y no debe esforzarse menos en estudiar que en practicar gimnasia; si no, [...] jamás alcanzará la meta del estudio supremo". ${ }^{40}$ Platón ratifica en la Carta VII esa idea de la ineludible obligación de curtirse psíquica, ética y corporalmente, de cara a una labor filosófica óptima: para poder acceder a la verdad noética, "es necesario [...] aprender [...] la verdad y lo falso del ser entero, a costa de mucho trabajo y mucho tiempo". ${ }^{41}$

Las consecuencias de esa perseverancia en el acondicionamiento intelectual y ético para el buen ejercicio de la filosofía son diversas. Una de ellas es la familiaridad del alma cognoscente con lo que ha de conocer y finalmente conoce. De acuerdo con lo que se lee en la Carta VII, la naturalidad conseguida en el manejo de un objeto de investigación, a fuer de una relación constante y prolongada con él, opera como una disposición que abre cauce a la experiencia de la verdad noética. En efecto, ésta habrá de acontecer por obra de "una larga convivencia con el problema y después de haber intimado con él". ${ }^{42}$ Unas pocas páginas más adelante, en dicho diálogo, Platón ratifica esta idea, en el contexto de sus relevantes consideraciones sobre los "elementos necesarios para que se produzca el conocimiento". ${ }^{43}$ El conocimiento que da razón del "quinto elemento" (el objeto en sí), presupone el manejo de todos los anteriores, "subiendo y bajando del uno al otro, a base de un gran esfuerzo". ${ }^{44}$ Afirmación que se corrobora, al dejar sentado que quien "no tiene ninguna afinidad con esta cuestión", ${ }^{45}$ por mucho que pueda poseer notables virtudes intelectuales, se verá impedido de captar lo real absoluto.

Por su parte, la familiaridad con lo que se investiga conecta con otro proceso de acondicionamiento del alma filosófica: su purificación. Para Platón, es

\footnotetext{
40 Platón, República: 504c-d

41 Platón, Carta VII: 344b

42 Platón, Carta VII: 341c

43 Platón, Carta VII: 342a

44 Platón, Carta VII: 343e

45 Platón, Carta VII: 344a
} 
sencillamente inconcebible que quienquiera, en cualquier momento, cuando le venga en gana, sin la disposición anímica adecuada, pueda tener una relación meridianamente estimable con lo real. Sócrates lo deja claro, en el libro IX de República:

Aquellos que carecen de experiencia de la sabiduría y de la excelencia y que pasan toda su vida en sus festines y cosas de esa índole son transportados hacia abajo y luego nuevamente hacia el medio y deambulan toda su vida hacia uno y otro lado, jamás han ido más allá de esto ni se han elevado, para mirar hacia lo verdaderamente alto ni se han satisfecho verdaderamente con lo real. ${ }^{46}$

En el último libro de República, Sócrates exige el cumplimiento de esa labor purificadora del alma en relación con el alma misma. Esta operación luce por completo relevante y pertinente de cara a los esfuerzos por demostrar la inmortalidad del alma, es decir, cuando ésta se convierte en objeto de su propio examen. Pero su efectividad representadora o cognitiva rebasa los límites de ese campo concreto, para proyectarse a todo proceso epistémico radical. Lo que en concreto plantea el filósofo a este respecto es que "para saber cómo es en verdad [el alma], debemos contemplarla no como la vemos ahora, estropeada por la asociación con el cuerpo y por otros males, sino que hay que contemplarla suficientemente con el razonamiento, tal cual es cuando llega a ser pura". ${ }^{47}$ El filósofo echa mano del sugerente símil de la figura de Glauco (dios del mar) con el "alma normal", para ilustrar su idea de su purificación. Así, de lo que se trata es de "sacarla del agua" para despojarla de todas las malas adherencias - "piedras y conchas" - de que está cubierta, a causa de su reprobable vida. Sólo "entonces se verá su verdadera naturaleza [...] qué es ella y cómo es". ${ }^{48}$ Si esa labor de acondicionamiento del alma es válida para investigarse a sí misma, no es disparatado considerar que lo sea todo otro objeto de interés heurístico.

Las referencias platónicas más vivaces en torno a la purga del alma como condición para el acceso a la realidad en sí están en Fedón. En este diálogo, Sócrates establece una distinción entre una suerte de "purificación por liberación definitiva", que se logra tras la muerte - esto es, con la separación del alma respecto del cuerpo-, y una depuración en permanente proceso, mientras el

46 Platón, Carta VII: 586a

47 Platón, Carta VII: 611c

48 Platón, Carta VII: 611e-612a 
alma permanece en la "prisión" del cuerpo en este mundo. La primera opción acontece de facto y tiene un alcance total; la segunda, siempre es parcial, demediada y sujeta a los vaivenes de la vida del cuerpo-alma que es la persona. Es esa segunda posibilidad la que interesa considerar aquí, por su carácter procesual, por darse a causa de una praxis de cariz ascético en el despliegue de la vida y en los dominios del devenir. De acuerdo con Sócrates, "mientras vivimos [...] según parece, estaremos más cerca del saber en la medida en que no tratemos ni nos asociemos con el cuerpo, a no ser en la estricta necesidad, y no nos contaminemos de la naturaleza suya, sino que nos purifiquemos de él, hasta que la divinidad misma nos libere". ${ }^{49}$ De lo antedicho se colige que sin algún modo de purificación del alma no es posible acceder a lo real; hay una opción purificadora total, definitiva, perfecta, por obra de la muerte, en cuyo caso, se trata de un evento determinado por la acción de una entidad - un ser divino - externa al alma. Existe, además, la posibilidad de una purga por iniciativa y obra de la propia alma cognoscente, en el encuadre de su existencia mundana, la cual supone una labor ético-epistémica específica y constante. Sin embargo, mientras quien procure conocer lo real viva en este mundo, no le será dado alcanzar una depuración completa e impecablemente acabada. Tal limitación no exime al filósofo de los esfuerzos del caso, a fin de avanzar en la ruta hacia la verdad noética. En el caso de la purificación anímica por muerte del cuerpo, hay una depuración físico-ética; en la posibilidad alterna, la purga acontece por obra de una liberación ética recurrente. Podría pensarse que este último aspecto determina el ejercicio de la dialéctica por parte del filósofo. Se diría que, visto desde la perspectiva socrático-platónica, ese método es parte de la actividad purificadora del alma, por lo que cabe considerar que se coloca en un plano supradianoético, aunque en lo que hace al diálogo sistemático, con base en estrictas determinaciones lógicas, se presenta con un fondo procedimental discursivo.

En principio, toda esa labor esforzada $-\mathrm{y}$ aun de tintes ascéticos - tiene su sentido último en el acontecer de la verdad noética, pero el discurso platónico da cuenta del fondo ontológico de esa experiencia. De acuerdo con Sócrates en Fedón, la purificación del alma se experimenta como la conciencia de la identidad esencial del alma cognoscente con la realidad en sí. Una vez despojadas nuestras almas de la consabida impedimenta corporal, dice

\footnotetext{
49 Platón, Fedón: 67a
} 
Sócrates, "estaremos en compañía de lo semejante", ${ }^{50}$ que es lo real absoluto. Y esto parece estar dando la señal de que esa identidad alma-realidad - sujeto-objeto, diríamos hoy - es la condición de necesidad (por su carácter ontológico) del acontecimiento noético, pues, agrega el filósofo, "al que no esté puro me temo que no le es lícito captar lo puro". ${ }^{51}$ Aprehender de manera inmediata lo que es en sí es posible en razón de una identidad ontológica de fondo entre las almas y la realidades eidéticas. El filósofo auténtico actualiza esa coincidencia por medio de la purificación de su psyché (Sócrates dice: "tiene preparada su inteligencia, como purificada"52), y ese logro se da como el cumplimiento de la referida identificación de los dos términos en relación.

Platón ratifica la idea de esa identidad o afinidad ontológica entre el alma cognoscente y su objeto de atención supremo en su Carta VII, cuando refiere que tras el esfuerzo intenso y prolongado de reflexión y, en general, de investigación filosófica, adviene "el conocimiento", en virtud de que "tanto el objeto como el espíritu están bien constituidos". ${ }^{53}$ El requisito de un "objeto bien constituido", en el contexto del discurso platónico, sólo puede entenderse como una entidad real en sí. Para Platón, no puede haber mejor opción de realidad bien formada. Puede observarse que, al reparar en el asunto de la relación alma-cosa, Platón se fija de nueva cuenta en el problema de los límites de la parte humana y anímica. El término problemático de esa conexión es el alma sometida al influjo determinante del cuerpo. De ahí el deber filosófico de lograr un "espíritu (un sujeto) bien constituido", como contraparte de un objeto del mismo carácter. Así, la purificación del alma deviene adecuación óntico-heurística de ésta con su referente objetual absoluto.

La purificación socrático-platónica del alma en este mundo, mientras ésta permanece en conexión ineludible con el cuerpo, es la que desata incitaciones teóricas más sugerentes y potentes, en comparación con lo imaginado en torno a una depuración anímica post-mortem. En las líneas precedentes se han examinado algunos aspectos relativos a los procesos, prácticas y caminos purificadores en el ámbito terrenal. Cabría todavía estudiar algunos elementos adicionales en su conexión con el acondicionamiento del alma de cara a la experiencia de la verdad noética. Por ejemplo, el de la oralidad -las sinuosidades del recurso al diálogo vivo, a la palabra que circula en el aire, en su

\footnotetext{
50 Platón, Fedón: 67a-b

51 Platón, Fedón: 67b

52 Platón, Fedón: 67c

53 Platón, Carta VII: 343e
} 
función de comunicar almas unidas por el interés común de acceder a la episteme suprema-, el del eros filosófico - tan fecunda y bellamente investigado en Banquete-, el de la libación intencional y controlada de vino como vía de acceso a la episteme. Abordarlos aquí y ahora sería un exceso, pero ello no obsta para tener en cuenta que se trata de dimensiones de la existencia humana en el mundo que, para el socratismo platónico, tienen significación teórica.

\section{Las implicaciones éticas y políticas de la episteme noética}

Las secuelas de la experiencia que comporta el acontecimiento de la episteme noética no se limitan a la impronta de la tablilla de cera del alma ni, con ello, a la afirmación de una memoria que va más allá de la facultad de evocar lo vivido, algo como una "memoria ontológica" que reconfigura en el alma del filósofo precisamente la visión originaria - previa a su caída en el mundo del devenir - de la realidad absoluta. En concreto, los efectos de la experiencia de la verdad noética, alcanzan al ethos, al carácter o modo de ser y a la conducta de quien la vive. Como pudo advertirse en el momento de examinar los aspectos que preparan y disponen al alma anhelante de verdad, Platón exige la purificación ética de aquella, como condición para el acontecimiento de la episteme noética. ${ }^{54}$ Pero sucede que la experiencia de ese evento, una vez que ha ocurrido, también reconstituye y fortalece al ethos.

En el libro vi de República, Sócrates ofrece una relación bastante amplia de las consecuencias que ocasiona en el filósofo auténtico la experiencia de la verdad:

el que ama realmente aprender es apto por naturaleza para aspirar a acceder a lo que es y no se queda en cada multiplicidad de cosas de las que se opina que son, sino que avanza sin desfallecer ni desistir de su amor antes de alcanzar la naturaleza de lo que es cada cosa, alcanzándola como parte del alma que corresponde a esto (y es la parte afín la que corresponde) por medio de la cual se aproxima a lo que realmente es y se funde con esto, engendrando inteligencia y verdad y obtiene conocimiento, nutrición y verdadera vida. ${ }^{55}$

54 Platón, Carta VII: 344a

55 Platón, República: 490a-b 
Por su parte, en Banquete, Diotima de Mantinea, hacia el final de su discurso - momento pletórico de referencias al "salto noético" posibilitado por el ejercicio teóricamente fecundo de la dialéctica - trata de dar cuenta de un modo determinado de la experiencia de la verdad como un "ver la belleza en sí, pura, limpia, sin mezcla y no infectada de carnes humanas ni de colores ni, en suma, de otras muchas fruslerías mortales", poco antes de dejar sentadas las consecuencias éticas de tal acontecimiento: "engendrar, no ya imágenes de virtud, al no estar en contacto con una imagen, sino virtudes verdaderas, ya que está en contacto con la verdad". Y, en derivación de lo dicho - según aclara la singular "maestra de Sócrates en asuntos de amor" - , ese poder creador de virtudes plenamente reales es propio ya de alguien que entra en el coto de la divinidad, culmen de la realización filosófico-humana. ${ }^{56}$

Con todo y que estos últimos pasajes platónicos son claros y fecundos, acaso sea el que cierra el libro IX de República el más hermoso y pregnante, en lo que hace a registrar los efectos suscitados por la visión de las realidades eidéticas. Recordemos que en ese punto del diálogo, Glaucón expresa sus dudas sobre la viabilidad del proyecto político que ha venido proponiendo Sócrates; incluso se diría que espera implícitamente de él un argumento válido en torno a tan relevante asunto. La respuesta del filósofo es bien conocida: "tal vez resida en el cielo un paradigma para quien quiera verlo $\mathrm{y}$, tras verlo, fundar un Estado en su interior. En nada hace diferencia, si dicho Estado existe o va a existir en algún lado, pues él actuará sólo en esa política y en ninguna otra". ${ }^{57}$ La experiencia de la verdad transforma para bien el ethos de quien la vive y en ello radica el fundamento de la política justa.

\section{Referencias bibliográficas}

Boeri, Marcelo D. (2017). "Dialéctica, pensamiento 'intuitivo' y 'discursivo' en Platón”. Tópicos (México), (52), 11-42.

BRAVO, Francisco. (2002). Teoría platónica de la definición. UCV (FEHE - CDCH).

BRAVO, Francisco. (2013). “¿Propone el Banquete una ciencia del amor?”. En Memoria del X Symposium Platonicum (Vol. 2, 129-134). The International Plato Society.

56 Platón, Banquete: 211c-212a

57 Platón, República: 592b 
CORNFORD, Francis M. (1983). La teoría platónica del conocimiento. Teeteto y El sofista: traducción y comentario. Paidós.

FronterotTA, Francesco. (2013). "La visione dell'idea del bello: conoscenza intuitiva e conoscenza proposizionale nel Simposio". En Memoria del X Symposium Platonicum (Vol. 2, 91-98). The International Plato Society.

Gosling, J. C. B. (1993). Platón. UnAM.

SZLEZÁK, Thomas Alexander. (2019). "La justificación de Platón acerca de su renuencia filosófica a escribir, en la sección filosófica de la Carta séptima de Platón (340b-345c)". En Jeannet Ugalde Quintana (Ed.), La interpretación alemana de Platón (49-63). Bonilla Artigas; UNAM.

VegetTI, Mario. (2012). Quince lecciones sobre Platón (Miguel Salazar, Trad.). Gredos. 